\title{
Gingival and oral hygiene conditions in patients with fixed orthodontic appliance wearers
}

\author{
Rini Anggraeni*), Isnaniah Malik*, Ina Hendiani** \\ *Department of Orthodontics Faculty of Dentistry Universitas Padjadjaran, Bandung \\ **Department of Periodontics Faculty of Dentistry Universitas Padjadjaran, Bandung
}

\begin{abstract}
The aim of this study was to get the description of gingival condition and oral hygiene in patients with fixed orthodontic appliance at Orthodontics Specialist Clinic of Oral and Dental Hospital Faculty of Dentistry Universitas Padjadjaran (RSGM FKG UNPAD) Bandung. This descriptive study with a survey method included 30 patients with fixed ortodontic appliances consist of 8 male and 22 females. The sample collected by purposive sampling. The data was collected based on filling questioner forms and clinical examination with assessed degree of gingival enlargement by Carranza, assessed Gingival Index by Loe and Silness, measured pocket depth, and assessed Plaque Index by Silness and Loe. The result showed that $90 \%$ of samples had gingival enlargement with varians of gingival enlargement degree from grade 1, 2, 3 and mostly present in posterior area. Prevalence of gingivitis was 100\% divided into $76.67 \%$ suffering mild gingivitis and $23.33 \%$ suffering moderate gingivitis. In examination of pocket depth, $6.67 \%$ had 1.1-2 mm of pocket depth; $70 \%$ had $2.1-3 \mathrm{~mm}$ of pocket depth; and $23.33 \%$ had $3.1-4 \mathrm{~mm}$. In examination of oral hygiene, $43.33 \%$ had good oral hygiene; $46.67 \%$ had moderate oral hygiene; and $10 \%$ had poor oral hygiene. Conclusion of this research was the orthodontics wearer suffering from gingival enlargement and mild gingivitis.
\end{abstract}

Key words: Gingival enlargement, gingivitis, pocket depth, oral hygiene, fixed orthodontic appliances

\section{ABSTRAK}

Alat ortodonti cekat dapat bertindak sebagai faktor iritan lokal yang mengakibatkan terjadinya akumulasi plak, gingivitis, peningkatan kedalaman poket dan gingival enlargement. Penelitian ini bertujuan untuk mendapatkan gambaran kondisi gusi dan kebersihan mulut pada pasien pemakai alat ortodonti cekat di Klinik Spesialis Ortodonti RSGM FKG UNPAD Bandung. Penelitian deskriptif metode survey ini dilakukan kepada 30 orang pasien yang terdiri dari 8 orang pria dan 22 orang wanita yang dipilih secara purposive sampling. Pengumpulan data dilakukan dengan pengisian kuesioner dan pemeriksaan klinis, yang meliputi penentuan derajat gingival enlargement menurut Carranza, penilaian indeks gusi menurut Loe dan Silness, pengukuran kedalaman poket, penilaian indeks plak menurut Silness dan Loe. Hasil penelitian menunjukkan bahwa $90 \%$ sampel mengalami gingival enlargement dengan derajat enlargement yang bervariasi dari grade 1, 2, 3 dan paling banyak terjadi di daerah posterior. Prevalensi gingivitis mencapai $100 \%$ dengan perincian gingivitis ringan $(76,67 \%)$ dan gingivitis sedang $(23,33 \%)$.

\footnotetext{
*)Correspondence author: Rini Anggraeni, Department of Periodontic Faculty of Dentistry Universitas Padjadjaran
} Jl. Sekeloa Selatan No. 1 Bandung, West Java-Indonesia, Tel./Fax: +6222-2504985/2532805 
Kedalaman poket 3, 1-4 mm (23,33\%). Kebersihan mulut, kategori baik (43,33\%), kategori sedang $(46,67 \%)$, dan kategori buruk (10\%). Simpulan penelitian ini adalah sebagian besar pasien memakai alat ortodonti cekat di RSGM FKG UNPAD Bandung mengalami gingival enlargement dan gingivitis ringan. Sebagian besar pasien memiliki kedalaman poket 2,1-3 mm. Sebagian besar pasien memiliki tingkat kebersihan mulut kategori baik dan sedang.

Kata kunci: Gingival enlargement, gingivitis, kedalaman poket, kebersihan mulut, alat ortodonti cekat

\section{INTRODUCTION}

One popular way of orthodontic treatment nowadays is fixed orthodontic appliance that is very popular among the people due to the increasing level of awareness of the importance of teeth arrangement as a support of the appearance and its impact on a person's psychological and career development. ${ }^{1}$ It can be seen from the high demand of patients for fixed orthodontic treatment in Faculty of Dentistry Padjadjaran University Teaching Hospital (RSGM FKG UNPAD).

The use of fixed orthodontic appliance may be indicated for a broader treatment because the appliance is able to move the teeth that cannot be moved by removable appliance. ${ }^{2}$ However, there are also several disavantages resulting from the use of fixed orthodontic appliance.

One of the problem that is often generated during the treatment using fixed orthodontic appliance is oral health problems. ${ }^{2}$ For patients with fixed orthodontic appliance, brushing teeth as an attempt to maintain oral health and hygiene will be more difficult. In addition, the presence of components of fixed orthodontic appliance in the oral cavity creates the retention of food debris and plaque accumulation often occurs, causing caries, gum inflammation, and periodontal disease. ${ }^{3}$

Research of Zachrisson and Zachrisson ${ }^{4}$ reported that in the patients with fixed orthodontic appliance, temporary changes occur in the gums condition during the treatment. The majority of patients with fixed orthodontic appliance experienced gingivitis with mild to moderate severity within 1 to 2 months after the installation of fixed orthodontic appliance. In addition, the increase in pocket depth that is not associated with attachment loss of the gingiva during treatment of fixed orthodontic appliance was also reported. ${ }^{5}$

Another study reported that the other conditions found during the fixed orthodontic treat- ment is gingival enlargement. This is supported by Kouraki's research ${ }^{5}$ which reported that the gingival enlargement is a common condition and can occur in patients with fixed orthodontic appliance with good oral hygiene level.

Based on these, the authors were interested in conducting research to find out the condition of the gingiva and oral hygiene in patients with fixed orthodontic appliance in Orthodontic Specialist Clinic RSGM FKG UNPAD.

\section{METHODS}

This research was a descriptive study with survey method. The population in this study were patients with fixed orthodontic appliance in Orthodontic Specialist Clinic RSGM FKG Unpad. Samples were taken by means of purposive sampling, in which patients, men and women, aged 18 years and over, with upper and lower fixed orthodontic treatment who came for controls in January 2006. Patients must also had no restoration of any kind on the teeth examined; had a good general condition; had no history of systemic and genetic diseases; were not pregnant or menstruating; did not use antibiotic drugs, anticonvulsant, immunosuppresants, or calcium channer blockers; did not smoking; and willing to been subjects of research.

Samples that met the criteria as much as 30 people were asked to fill in informed consents. Samples may be seated in a chair provided then asked to rinse and an assessment was done of the teeth selected based on Ramfjord method, for teeth as follows $16,21,24,36,41$, and 44 . If the tooth was missing, the tooth next to it with a similar anatomical shape and located in one regio were then used. Assessment involves the determination of the gingival enlargement degree according to Carranza; Assessment of gingival index according to Loe and Sillness; Pocket depth 
measurements; as well as examination of plaque index according to Sillness and Loe. The data were then grouped, processed and the results of the study were presented in tabular form.

\section{RESULT}

Result of this study presented in Table 1-4.

\section{DISCUSSION}

Based on the results of the study, $90 \%$ sample of fixed orthodontic appliance users experiencing gingival enlargement with varying degrees

Table 1. Sample distribution of the site of gingival enlargement

\begin{tabular}{lcccc}
\hline \multirow{2}{*}{ Region } & \multicolumn{4}{c}{ Gingival enlargement } \\
\cline { 2 - 5 } & \multicolumn{2}{c}{ Yes } & \multicolumn{3}{c}{ No } \\
\cline { 2 - 5 } & Total & $\%$ & Total & $\%$ \\
\hline Upper anterior & 3 & 11.11 & 24 & 88.89 \\
Lower anterior & 6 & 22.22 & 21 & 77.78 \\
Upper posterior & 25 & 92.59 & 2 & 7.41 \\
Lower posterior & 22 & 81.48 & 5 & 18.52 \\
\hline
\end{tabular}

Table 2. Sample distribution of the dental conditions

\begin{tabular}{lcc}
\hline \multicolumn{1}{c}{ Severity of gingivitis } & Total & $\%$ \\
\hline Mild gingivitis & 23 & 76.67 \\
Moderate gingivitis & 7 & 23.33 \\
severe gingivitis & 0 & 0 \\
Experienced gingival enlargement & 27 & 90 \\
No experienced gingival enlargement & 3 & 10 \\
\hline
\end{tabular}

Table 3. Sample distribution of pocket depth

\begin{tabular}{ccc}
\hline Average pocket depth & Total & $\%$ \\
\hline $1.1-2$ & 2 & 6.67 \\
$2.1-3$ & 21 & 70 \\
$3.1-4$ & 7 & 23.33 \\
\hline Total & 30 & 100 \\
\hline
\end{tabular}

Tabel 4. Sample distribution of oral hygiene level

\begin{tabular}{lcc}
\hline \multicolumn{1}{c}{ Oral hygiene level } & Total & $\%$ \\
\hline Very good & 0 & 0 \\
Good & 13 & 43.33 \\
Moderate & 14 & 46.67 \\
Bad & 3 & 10 \\
\hline Total & 30 & 100 \\
\hline
\end{tabular}

of gingival enlargement of grade 1,2 , and 3 . The results were consistent with previous studies which reported that the gingival enlargement was a common condition that occurs in users of fixed orthodontic appliance. ${ }^{5}$ Gingival enlargement in fixed orthodontic appliance users can occur due to several factors, namely the retention of ongoing plaque, irritation from the use of orthodontic bands, chemical irritation of the cement used, or due to pressure of orthodontic appliance itself. ${ }^{6-8}$

According to the research, gingival enlargement was known to occur both in the region of the anterior and posterior region of the maxilla and mandible. However, this condition has a tendency to occur more frequently in the posterior region of both the maxilla and $92.59 \%$ on the lower jaw of $81.48 \%$. The results are consistent with the Kloehn and Pfeifer ${ }^{9}$ reported that the gingival enlargement in fixed orthodontic appliance users occurs more frequently in the posterior region. There are 4 reasons why gingival enlargement is more common in the posterior region, which is due to mechanical irritation from orthodontic bands that come into contact with the gingival margin; the chemical irritation of the gingival margin of cement when setting up the band; of food impaction between the archwire and the soft tissues; and tendency of accuracy and effectiveness of tooth brushing on the anterior than posterior.

The results of this study indicated that the overall orthodontic fixed appliance user experience gingivitis with severity ranging from mild gingivitis by $76.67 \%$ to $23.33 \%$ is for the average gingival index of 0.72 . This is consistent with previous studies which reported that the majority of users of fixed orthodontic appliance having gingivitis with mild to moderate severity. This condition is closely related to the accumulation of bacterial plaque because fixed orthodontic appliance is a local irritant causing plaque retention. ${ }^{8,10}$ In addition, according to Thurow ${ }^{11}$ mechanical properties of orthodontic appliance itself creates the pressure and causes injury to the gingival tissue is inflamed reversibly.

Based on the results of pocket depth measurements in mind that the average pocket depth of 2.1-3 mm have more fixed orthodontic appliance wearers and the average pocket depth at fixed orthodontic appliance wearers was $2.71 \mathrm{~mm}$. These results are not consistent with the Kloehn 
and Pfeifer ${ }^{9}$ research mentioned that the wearer of fixed orthodontic appliance during treatment increased pocket depth. Possible causes of this difference is the method of calculating the pocket depth was recorded pocket depth. Possible causes of this difference is the way different pocket depth calculation. In a study Kloehn and Pfeifer ${ }^{9}$ pocket depth was recorded into the deepest pockets in the pocket while this study is the result of the average pocket depth of four surfaces of each tooth is examined.

Nevertheless, the results of this study show that pocket depth in areas experiencing gingival enlargement in fixed orthodontic appliances were also increasing without experiencing epithelial attachment loss. This happens because in the case of gingival enlargement, gingival pocket also occurred, which is an increase in gingival sulcus depth without periodontal tissue destruction, caused by the enlargement of the gums towards the crown. ${ }^{8}$

According to the results of this study, the level of oral hygiene on a fixed orthodontic appliance users ranging from the good level of oral hygiene category $(43.33 \%)$, the category average (46.67\%) even worse category (10\%). Average plaque indices at fixed orthodontic appliance users of 1.01. The result is in accordance with previous researchers who mentioned that the problem of oral hygiene is the main drawback of fixed orthodontic appliance. The existence of fixed orthodontic appliance components in the oral cavity allows food retention and accumulation of plaque, and makes the users difficult to clean the plaque to the fullest.

Therefore, the act of oral health care through the prevention of plaque buildup that can damage the teeth and periodontal tissues is an important thing to be done by users of fixed orthodontic appliance. This can be done mechanically by the action of brushing teeth or chemical action such as by using a mouthwash. ${ }^{12,13}$

Brushing teeth in fixed orthodontic appliance users can be done with a manual toothbrush with a special design manually or by using an electric toothbrush. Horizontal brushing method combined with the vibration method is also recommended. Frequency and timing of brushing teeth recommended for users of fixed orthodontic appliance is 2 times a day, after breakfast and before bedtime. Users are also advised to clean your teeth immediately after eating to remove food debris. $3,12,13$

According to the results of filling the questionnaire conducted, most users of fixed orthodontic appliance replied that the frequency of brushing is usually done 2 to 3 times a day. Most users of fixed orthodontic appliance brushed their teeth in the shower in the morning and before bedtime. Only a small proportion of fixed orthodontic appliance users cleaned his teeth immediately after eating or brushing teeth after breakfast and before bedtime. Types of toothbrushes used by most users fixed orthodontic appliance is a toothbrush designed specifically for users of fixed orthodontic appliance with bristle brush hardness level of soft to medium. The most widely method of brushing used is the method of horizontal and, according to the results of the questionnaire, only a small portion of fixed orthodontic appliance users used mouthwash as a chemical action.

However, thorough plaque removal efficiency is the most important thing to be noted. Therefore, the use of additional tools such as dental floss, toothpicks, interdental toothbrushes, as well as oral irrigation tool can be used to clean areas that are not reached by toothbrush. ${ }^{12,13}$

\section{CONCLUSION}

The majority of patients with fixed orthodontic appliance users in RSGM FKG UNPAD Bandung experienced gingival enlargement and mild gingivitis. Most of the patients had a pocket depth 2.1 to $3 \mathrm{~mm}$. Most patients were categorized to have good and moderate oral hygiene level.

\section{REFERENCES}

1. Williams JK, Cook PA, Isaacson KG. Fixed orthodontic appliance. Jakarta: EGC; 1995.

2. Foster TD. Buku ajar ortodonti. $3^{\text {th }}$ ed. Jakarta: EGC; 1997. p. 300.

3. Bishara SE. Textbook of orthodontics. Philadelphia: W.B. Saunders Co.; 2001. p. 112, 259-63.

4. Zachrisson JS, Zachrisson BU. Gingival condition associated with orthodontic treatment. J 
Angle Orthod 1972;42:26-34.

5. Kouraki E, Bissada JM, Palomo. Gingival enlargement and resolution during and after orthodontic treatment. J New York Dental State 2005;71:34-7 [cited 2005 Sep 24]. Available from: http://www.Amedeo.com/ medicine/ped/pedg htm.

6. Viazis A. Atlas of orthodontics principles and clinical applications. Philadelphia: W.B. Saunders; 1993.

7. Ong MA, Wang FNS. Interrelationship between periodontics and adult orthodontics. J Clin Periodontol 1998;25:271-77.

8. Carranza M, Newton G. Clinical periodonto- logy. $9^{\text {th }}$ ed. USA: W.B. Saunder; 2002.

9. Kloehn JS, Pfeifer JS. The effect of orthodontic treatment on the periodontium. J Angle Orthod 1974;44:127-34.

10. Manson JD, Eley B. Buku ajar periodontologi. $2^{\text {th }}$ ed. Jakarta: Hipokrates; 1993.

11. Thurow RC. Edgewise orthodontics. St. Louis: Mosby; 1982.

12. Houwink B, Dirks OB, Cramwinckel AA. Ilmu kedokteran gigi pencegahan. Jakarta: Hipokrates; 1993.

13. Heintz 0 , Norman GC, Arden. Primary preventive dentistry. $4^{\text {th }}$ ed. Norwalk: Appleton and Large; 1995. 